\title{
Filming the Family: A Documentary Film to Educate Clinicians about Family Caregivers of Patients with Brain Tumors
}

\author{
Michael W. Rabow • Steffanie Goodman • \\ Susan Chang • Mitchel Berger • Susan Folkman
}

Published online: 30 March 2010

(C) The Author(s) 2010. This article is published with open access at Springerlink.com

\begin{abstract}
The objective of this paper is to evaluate the educational value of a documentary film about family caregiving for patients with brain tumors. The method used in this study is a pre-post survey among neurosurgeons, neuro-oncologist, and other clinician viewers. Viewers evaluated the film highly and reported an intention to change their practice as a result of watching the film. Following viewing, participants felt more strongly that "all families of patients with brain cancers should meet with a social worker" $(P=0.01)$ and that "family caregivers greatly impact the health of patients" $(P=0.002)$, and they were less likely to believe that "supporting family caregivers is primarily someone else's job" $(P=0.009)$. A documentary
\end{abstract}

Sources of Funding The Caregivers Project is supported by funds from the Langeloth Foundation, the Arthur Vining Davis Foundation, and the Mental Insight Foundation.

M. W. Rabow $\cdot$ S. Folkman

Department of Medicine, University of California,

San Francisco, CA, USA

S. Goodman $\cdot$ S. Folkman

Osher Center for Integrative Medicine, University of California,

San Francisco, CA, USA

S. Chang

Department of Neurological Surgery,

Program in Neuro-Oncology, University of California,

San Francisco, CA, USA

M. Berger

Department of Neurological Surgery, University of California,

San Francisco, CA, USA

M. W. Rabow $(\square)$

UCSF/Mount Zion,

1701 Divisadero St, \#500,

San Francisco, CA 94143-1732, USA

e-mail: mrabow@medicine.ucsf.edu film about family caregiving is an effective educational tool to increase awareness among neurosurgery/neuro-oncology clinicians about the importance and needs of family caregivers of patients with brain tumors.

Keywords Brain tumor Family caregiver.

Medical education

\section{Introduction}

Although physician and family caregivers of patients with brain tumors share numerous goals (including appropriate, safe, and effective curative or palliative treatment of tumors, patient symptom control, and patient treatment adherence), physicians and family caregivers often know little about the experience of the other. Physicians depend on family caregivers to be the medical representative in the patient's home, yet physicians are generally unaware of the significant costs, morbidity, and even mortality associated with family caregiving, and typically have only limited support in working with them [1-6]. Physicians who do not understand the demands family caregivers face and the depth of their commitment may discount the work of family caregivers, fail to support it adequately, or even become resentful of the caregiver's involvement [7].

The visual arts have been used to help physicians and medical students better understand the experience of patients and to instill empathy [8-11]. We developed a documentary film detailing the experiences of family caregivers of patients with brain tumors to increase learner awareness about family caregivers. Here, we present initial data evaluating the impact of the film and provide information about how to access the film and accompanying viewer discussion guide. 


\section{Methods}

The UCSF Department of Neurological Surgery and the Osher Center for Integrative Medicine collaborated on a project entitled "The Caregivers Project" with the goal of producing and distributing a documentary film designed to improve neurosurgery training around supporting family caregivers.

\section{Film Development}

We held two 2-h focus groups with eight to ten UCSF neurosurgery residents and fellows to identify common attitudes about family caregivers and issues of conflict in the physician/family caregiver relationship during neurosurgery training. We also held a 2-h focus group with 12 family caregivers of patients with brain tumors to identify their common wishes and needs for relating to neurosurgeons. We consulted with national experts in family caregiving and major brain tumor advocacy and support organizations (including the American Brain Tumor Association and the National Brain Tumor Foundation).

\section{Film Content}

Initial focus group and consultation information informed the design and content of a 48-min documentary film, "The Caregivers" (see Table 3) directed by Andy Abrahams Wilson, an award-winning documentary and educational film director and producer with experience filming medical subjects (http://www.openeyepictures.com). "The Caregivers" depicts the stories of four family caregivers of

Table 1 Baseline family caregiver attitudes among neurosurgeons, neurosurgery residents, medical students, and non-physician clinicians

\begin{tabular}{|c|c|c|c|c|}
\hline Baseline attitude & Group & $\begin{array}{l}\text { Group mean, } 1-10 \text { scale: }(1=\text { strongly } \\
\text { disagree } 10=\text { strongly agree }) N=61\end{array}$ & $\begin{array}{l}\text { ANOVA } \\
F \text { statistic }\end{array}$ & $P$ value \\
\hline \multirow{4}{*}{$\begin{array}{l}\text { 1. Giving attention to family caregivers is a } \\
\text { good use of my limited time }\end{array}$} & NS/NO & 7.73 & \multirow[t]{4}{*}{1.52} & \multirow[t]{4}{*}{0.22} \\
\hline & NSR & 8.57 & & \\
\hline & MS & 8.60 & & \\
\hline & Non-MD & 9.11 & & \\
\hline \multirow{4}{*}{$\begin{array}{l}\text { 2. I have time to care for family caregivers } \\
\text { the way I'd like }\end{array}$} & $\mathrm{NS} / \mathrm{NO}$ & 4.64 & \multirow[t]{4}{*}{1.47} & \multirow[t]{4}{*}{0.23} \\
\hline & NSR & 5.57 & & \\
\hline & MS & 4.27 & & \\
\hline & Non-MD & 6.29 & & \\
\hline \multirow{4}{*}{$\begin{array}{l}\text { 3. All families of patients with brain cancers } \\
\text { should meet with a social worker }\end{array}$} & NS/NO & 9.08 & \multirow[t]{4}{*}{1.65} & \multirow[t]{4}{*}{0.19} \\
\hline & NSR & 7.86 & & \\
\hline & MS & 8.73 & & \\
\hline & Non-MD & 9.39 & & \\
\hline \multirow{4}{*}{$\begin{array}{l}\text { 4. Family caregivers are very important in } \\
\text { the care of patients } \\
\text { with brain cancers }\end{array}$} & NS/NO & 9.92 & \multirow[t]{4}{*}{1.09} & \multirow[t]{4}{*}{0.36} \\
\hline & NSR & 9.57 & & \\
\hline & MS & 9.73 & & \\
\hline & Non-MD & 9.87 & & \\
\hline \multirow{4}{*}{$\begin{array}{l}\text { 5. Most family caregivers need special } \\
\text { attention from their family member's } \\
\text { physician }\end{array}$} & NS/NO & 6.46 & \multirow[t]{4}{*}{2.79} & \multirow[t]{4}{*}{$0.05^{\mathrm{a}}$} \\
\hline & NSR & 8.14 & & \\
\hline & MS & 8.60 & & \\
\hline & Non-MD & 8.26 & & \\
\hline \multirow{4}{*}{$\begin{array}{l}\text { 6. Family caregivers greatly impact the health } \\
\text { of patients }\end{array}$} & $\mathrm{NS} / \mathrm{NO}$ & 9.69 & \multirow[t]{4}{*}{7.75} & \multirow[t]{4}{*}{$<0.001^{\mathrm{a}}$} \\
\hline & NSR & 7.57 & & \\
\hline & MS & 9.82 & & \\
\hline & Non-MD & 9.58 & & \\
\hline \multirow{4}{*}{$\begin{array}{l}\text { 7. Given my role on the clinical team, I believe } \\
\text { that supporting family caregivers is primarily } \\
\text { someone else's job. }\end{array}$} & $\mathrm{NS} / \mathrm{NO}$ & 2.08 & \multirow[t]{4}{*}{7.99} & \multirow[t]{4}{*}{$<0.001^{\mathrm{a}}$} \\
\hline & NSR & 4.43 & & \\
\hline & MS & 5.27 & & \\
\hline & Non-MD & 1.82 & & \\
\hline
\end{tabular}

NS/NS neurosurgeons and neuro-oncologists (academic faculty or community), NSR neurosurgery residents, $M S$ medical student, Non-MD nonphysician clinician

${ }^{\text {a }}$ Statistically significant 
Table 2 Pre-film versus post-film viewing family caregiver attitudes among neurosurgeons, neuro-oncologists, neurosurgery residents, medical students, and non-physician clinicians

\begin{tabular}{|c|c|c|c|}
\hline Attitude question & & $\begin{array}{l}\text { Response mean } 1-10 \text { scale: }(1=\text { strongly } \\
\text { disagree } 10=\text { strongly agree }) N=57\end{array}$ & $\begin{array}{l}P \text { value for paired } \\
\text { sample difference }\end{array}$ \\
\hline $\begin{array}{l}\text { 1. Giving attention to family caregivers is a good use } \\
\text { of my limited time. }\end{array}$ & $\begin{array}{l}\text { Pre } \\
\text { Post }\end{array}$ & $\begin{array}{l}8.77 \\
8.75\end{array}$ & 0.88 \\
\hline 2. I have time to care for family caregivers the way I'd like. & $\begin{array}{l}\text { Pre } \\
\text { Post }\end{array}$ & $\begin{array}{l}5.44 \\
5.30\end{array}$ & 0.67 \\
\hline $\begin{array}{l}\text { 3. All families of patients with brain cancers should meet } \\
\text { with a social worker. }\end{array}$ & $\begin{array}{l}\text { Pre } \\
\text { Post }\end{array}$ & $\begin{array}{l}8.95 \\
9.49\end{array}$ & $0.01^{\mathrm{a}}$ \\
\hline $\begin{array}{l}\text { 4. Family caregivers are very important in the care of } \\
\text { patients with brain cancers. }\end{array}$ & $\begin{array}{l}\text { Pre } \\
\text { Post }\end{array}$ & $\begin{array}{l}9.81 \\
9.83\end{array}$ & 0.81 \\
\hline $\begin{array}{l}\text { 5. Most family caregivers need special attention from } \\
\text { their family member's physician. }\end{array}$ & $\begin{array}{l}\text { Pre } \\
\text { Post }\end{array}$ & $\begin{array}{l}8.12 \\
9.39\end{array}$ & 0.45 \\
\hline 6. Family caregivers greatly impact the health of patients. & $\begin{array}{l}\text { Pre } \\
\text { Post }\end{array}$ & $\begin{array}{l}9.40 \\
9.74\end{array}$ & $0.002^{\mathrm{a}}$ \\
\hline $\begin{array}{l}\text { 7. Given my role on the clinical team, I believe that } \\
\text { supporting family caregivers is primarily someone else's job }\end{array}$ & $\begin{array}{l}\text { Pre } \\
\text { Post }\end{array}$ & $\begin{array}{l}2.85 \\
2.31\end{array}$ & $0.009^{\mathrm{a}}$ \\
\hline
\end{tabular}

${ }^{\text {a }}$ Statistically significant pre-post difference

adult loved ones with a brain tumor. The project leaders (MR, SG, SF) worked with the filmmaker before and throughout filming and editing so that the film would reflect focus group themes and evidence-based content about family caregiver issues. All involved physicians, residents, patients, and family caregivers gave their consent to appear in the film.

\section{Evaluation Tool}

A tool was developed to assess film quality and attitudes toward family caregivers as well as any change in these attitudes after viewing the film. The survey was revised in consultation with researchers from the Educational Research Program of the UCSF Office of Medical Education.

\section{Viewers}

The completed film was shown to the 2007-08 UCSF neurosurgery residents and fellows not involved in the prior focus groups, UCSF medical students enrolled in an elective class about cancer, and at screenings at national conferences for neurosurgeons, neuro-oncologists, interdisciplinary care teams, and medical educators. All screenings were advertised via posters and pamphlets and were elective.

Prior to viewing the film, viewers completed the demographic and attitude sections of the survey. Immediately afterwards and prior to any facilitated discussion, viewers assessed the film's quality and answered the attitude questions a second time. Surveys were submitted anonymously.

\section{Data Analysis}

Survey responses were double-entered into an Excel(C) database and analyzed with SPSSC statistical software. $t$ tests for paired samples and independent samples, and one-way analysis of variance without correction for multiple comparisons were used to analyze means and differences in group means. Statistical significance was given as $P \leq 0.05$.

\section{Institutional Review}

Approval was obtained for the study by the UCSF Committee on Human Research prior to all focus groups and data collection.

\section{Results}

\section{Response Rate}

All but two viewers completed the evaluation at the UCSF viewings. The proportion of viewers nationally among all those invited to the screenings is unknown.

Table 3 Screening "The Caregivers" film

Readers interested in watching a trailer for "The Caregivers" film can view it free-of-charge online at http://www.openeyepictures. com/thecaregivers/.

A DVD copy of the film and its accompanying discussion facilitator guide may be ordered by emailing Fanlight Productions at info@fanlight.com or by visiting the website www.fanlight.com. 
Study Population

Sixty-one surveys with complete evaluation data were included in the analysis. Participants included neurosurgeons, neuro-oncologists, neurosurgery residents, medical students, and non-physician clinicians (nurses, chaplains, and social workers).

\section{Baseline Attitudes}

At baseline, neurosurgery residents were less likely than both neurosurgeons/neuro-oncologists and non-physician clinicians to believe that "family caregivers greatly impact the health of patients" (independent samples $t$ test $P=0.04$ and $P=0.05$, respectively; Table 1). Medical students were more likely than neurosurgeons/neuro-oncologists to believe that "supporting family caregivers is primarily someone else's job" (independent samples $t$ test, $P=0.004$ )

\section{Film Evaluation}

All viewers felt that the film was of high quality ( 9.27 on a ten-point Likert scale) and important (9.03), that they learned something useful from the film (8.67), and that the film is an effective way to teach about family caregivers (8.98), and should be seen by all clinicians caring for patients with brain tumors (9.23).

\section{Pre-Post Changes}

After viewing of the film, viewers were more likely to agree that "all families of patients with brain cancers should meet with a social worker" $(P=0.01)$ and that "family caregivers greatly impact the health of patients" $(P=0.002)$. They were less likely to believe that "supporting family caregivers is primarily someone else's job" $(P=0.009$; Table 2).

\section{Discussion}

A documentary film about the experience of family caregivers of patients with brain tumors, viewed by neurosurgeons, neuro-oncologists, neurosurgery residents, medical students, and non-physician clinicians, was wellreceived and reported to be important, relevant, and useful. Viewers thought that the film was an effective way to teach about family caregivers and that all clinicians caring for brain tumor patients should see the film.

At baseline, medical students and neurosurgery residents attributed less significance to family caregiving than did their seniors. It appears that over time, clinical and perhaps life experience affect how clinicians understand the role of family caregivers and their own role in supporting them.

Given the power of the stories told, it is not surprising that viewers came away with stronger beliefs that "all families of patients with brain cancers should meet with a social worker" and that "family caregivers greatly impact the health of patients." Viewers were more likely to disagree that "supporting family caregivers is primarily someone else's job."

These pilot data should be viewed only as suggestive. The relatively small study sample was self-selected, there was no control group, the clinical significance of the statically significant findings has not been validated, and the duration of demonstrated changes in attitude is unknown. Nevertheless, viewing a documentary film about family caregivers affords clinicians a perspective on the experiences of family caregivers that complements the clinicians' formal curriculum and clinical work. Although the data from this study are preliminary, there is reason to believe that viewing "The Caregivers" is a useful education intervention for increasing awareness of the role of the family caregiver, especially when combined with ongoing discussion and positive role modeling around the themes explored in the film.

Copies of the film and a facilitator's discussion guide to explore issues raised by the film are available (Table 3).

\section{Conflicts of interest None}

Open Access This article is distributed under the terms of the Creative Commons Attribution Noncommercial License which permits any noncommercial use, distribution, and reproduction in any medium, provided the original author(s) and source are credited.

\section{References}

1. Rabow MW, Hauser JM, Adams J (2004) Supporting family caregivers at the end of life: "they don't know what they don't know". JAMA 291:483-491

2. Schulz R, Beach S (1999) Caregiving as a risk factor for mortality. The caregiver health effects study. JAMA 282:22152219

3. Donelan K, Hill CA, Hoffman C et al (2002) Challenged to care: informal caregivers in a changing health system. Health Aff 21:222-231

4. Schubart JR, Kinzie MB, Farace E (2008) Caring for the brain tumor patient: family caregiver burden and unmet needs. Neuro Oncology 10:61-72 
5. Lang DA, Neil-Dwyer G, Garfield J (1999) Outcome after complex neurosurgery: the caregivers burden is forgotten. J Neurosurg 91:359-363

6. Schubart JR, Kinzie MB, Farace E (2008) Caring for the brain tumor patient: family caregiver burden and unmet needs. Neuro Oncology 10:61-72

7. Levine C, Zuckerman C (1999) The trouble with families: toward an ethic of accommodation. Ann Intern Med 130:148-152

8. Lorenz KA, Steckart MJ, Rosenfeld KE (2004) End-of-life education using the dramatic arts: the Wit educational initiative. Acad Med 79:481-486

9. Weber CM, Silk H (2007) Movies and medicine: an elective using film to reflect on the patient, family, and illness. Fam Med 39:317-319

10. Self DJ, Baldwin DC (1990) Teaching medical humanities through film discussions. J Med Humanit 11:23-29

11. Kumagai AK (2008) A conceptual framework for the use of illness narratives in medical education. Acad Med 83:653-658

\section{Author Contributions}

Michael W. Rabow, MD, co-facilitated the focus groups, developed the evaluation tool, conducted the data analysis, and wrote the first draft of the manuscript.

Steffanie Goodman, MPH, co-facilitated the focus groups, supervised film screenings, collected and entered the data, and wrote revisions of the manuscript.

Susan Chang, MD, assisted with data collection, assisted with project design, and wrote revisions of the manuscript.

Mitchel Berger, MD, co-facilitated the focus groups, assisted with project design, and wrote revisions of the manuscript.

Susan Folkman, PhD, obtained project funding, co-facilitated the focus groups, assisted with project design, assisted with data analysis, and wrote revisions of the manuscript. 